\title{
ANÁLISE GENÉTICA DE SALMONELLA TYPHIMURIUM FERMENTADORAS DE LACTOSE ISOLADAS NO RIO DE JANEIRO
}

\author{
Fernando Portela Câmara, Maria Amélia Cardoso e \\ Darcy Fontoura de Almeida
}

\begin{abstract}
Salmonella typhimurium fermentadoras de lactose são comuns em São Paulo, porém, raras no Rio de Janeiro, onde descrevemos dois isolamentos. Um plasmídeo de 7,4 megadáltons, não auto-transferivel, termorresistente e não eliminável pelo alaranjado de acridina foi identificado em cada uma das duas linhagens isoladas no Rio de Janeiro. O fato de uma dessas linhagens ser derivada de um plasmídeo que originalmente não expressa o caráter fermentação de lactose, permite-nos especular acerca da origem deste caráter nas Salmonellas brasileiras.
\end{abstract}

Palavras-chaves: Salmonella fermentadoras de lactose. Salmonella typhimurium. Plasmídeo. Epidemiologia de Salmonella.

Em 1975, Suassuna e cols, 14 comunicaram o isolamento de uma $S$. typhimurium fermentadora de lactose no Rio de Janeiro, em um caso de gastroenterite infantil apresentado como autóctone. Essa linhagem, denominada H975, era resistente ao cloranfenicol, canamicina, cefalotina e sulfadiazina, e não pertencia a fagotipos conhecidos. Exceto pela não resistência à tetraciclina, as características citadas levaram Suassuna e cols 14 a conclúrem ser a linhagem H975 semelhante àquelas então endêmicas em São Paulo, e que este isolamento poderia significar o indício de uma extensão desta situação para o Rio de Janeiro. O caráter fermentação de lactose em Salmonella está associado a um plasmídeo de resistência a drogas antibacterianas 110 . Plasmídeos Rlac são provavelmente formados pela inserção de um operon lactose de Escherichia coli em um plasmideo R através de um elemento de transposição ${ }^{8}$.

Outra $S$. typhimurium portadora de um plasmídeo Rlac foi encontrada por Câmara ${ }^{4}$, entre salmonelas lactose-negativas isoladas de esgotos da cidade do Rio de Janeiro5. Esta Salmonella foi originalmente isolada como lactose negativa, entretanto, notou-se que após 48 horas de incubação as colônias apresentavam papilas vermelhas em agar MacConkey, indicando fermentação ativa de lactose ${ }^{4}$. Estas papilas eram isoladas como clones tipicamente fermentadores do lactose e foram designados como

Instituto de Microbiologia da Universidade Federal do Rio de Janeiro e Instituto de Biofísica Carlos Chagas Filho, Universidade Federal do Rio de Janeiro-Rio de Janeiro, RJ.

Endereço para correspondência: Prof. Fernando Portela Câmara. Instituto de Microbiologia/UFRJ - Caixa Postal: 68040 - 21944 Rio de Janeiro, RJ.

Recebido para publicação em 10/2/89. linhagem E10f enquanto a linhagem original da qual derivou foi designada E10. Toledo e cols ${ }^{15}$ relataram o isolamento de $\boldsymbol{S}$. typhimurium semelhantes à E10, em material clínico, na cidade de São Paulo. Esses autores consideram tais linhagens como "fermentadoras tardias de lactose".

$O$ presente trabalho estuda as propriedades genéticas das linhagens $\mathrm{H} 795$ e E10f de $S$. typhimurium isoladas na cidade do Rio de Janeiro, Brasil.

\section{MATERIAL E MÉTODOS}

Bactérias utilizadas - Ver Tabela 1.

Meios utilizados

Foram utilizados o caldo triptona-extrato de levedura (TE) ${ }^{12}$ e agar MacConkey (BBL). A seleção dos transconjugantes foi realizada em agar MacConkey seletivo contendo rifampicina $(100 \mathrm{ug} / \mathrm{ml})$ e ampicilina $(20 \mathrm{ug} / \mathrm{ml})$ ou tetraciclina $(40 \mathrm{ug} / \mathrm{ml})$.

\section{Estabilidade do plasmídeo}

Foi testada na presença de alaranjado de acridina $(50 \mathrm{ug} / \mathrm{ml})$ segundo a técnica de Clowes \& Hayes ${ }^{6}$ usando a $E$. coli $\mathrm{RV} / \mathrm{F}^{\prime}$ lac como controle (com perda do caráter lac acima de $95 \%$ na condição indicada). Para testar a termoestabilidade de plasmideo ${ }^{16}$, culturas foram crescidas a 30,37 e $42^{\circ} \mathrm{C}$ durante 24 a 72 horas e pelo menos 100 colônias foram testadas pelo método de "replica plating".

\section{Produção de colicina}

Foi realizada segundo a técnica de Meynell \& Meynell ${ }^{11}$ usando $E$. coli C600 como linhagem ${ }^{1} \mathrm{Lac}+\mathrm{Em} \mathrm{Ap} \mathrm{Cf} \mathrm{Ct} \mathrm{Sd} \mathrm{Tc} \mathrm{Cm} \mathrm{GmST}$

\section{Conjugação}

Culturas em início de fase log (caldo TE) das linhagens doadoras e receptoras eram diluídas 1:10, 
Tabela 1 - Bactérias utilizadas neste trabalho.

\begin{tabular}{|c|c|c|c|}
\hline Linhagens & Características & Uso & Procedência \\
\hline $\begin{array}{l}\text { S. typhimurium } \mathrm{H} 975 \\
\text { S. typhimurium } \mathrm{E} 10 \mathrm{f} \\
\text { E. coli } \mathrm{RV} / \mathrm{F} \text { 'lac } \\
\text { E. coli } \mathrm{C} 600 \\
\text { E. coli LR-1 } \\
\text { P. mirabilis } \text { PM51 }\end{array}$ & $\begin{array}{l}{ }^{1} \mathrm{Lac}^{+} \text {Em Ap Cf Ct Sd } \\
{ }^{1} \mathrm{Lac}^{+} \text {Em Ap CfCt Sd Tc Cm GmST } \\
{ }^{1} \mathrm{~F}^{\mathrm{F}} \mathrm{lac} / \Delta \mathrm{lac}_{\mathrm{x} 74} \\
{ }^{2} \mathrm{lac} \text { thr leu thi } \\
{ }^{2} \mathrm{C} 600 \mathrm{Rf} \\
{ }^{3} \mathrm{RTF}\end{array}$ & $\begin{array}{l}\text { doadora } \\
\text { doadora } \\
\text { doadora } \\
\text { indicadora } \\
\text { receptora } \\
\text { mobilizadora }\end{array}$ & $\begin{array}{l}\text { Dr. J. C. Andrade } \\
\text { Nosso laboratório } \\
\text { Dr. J. Walker } \\
\text { Nosso laboratório } \\
\text { Nosso laboratório } \\
\text { Dr. D. Santos }\end{array}$ \\
\hline
\end{tabular}

1. fenótipo plasmidial

2. Fenótipo cromossòmico

3. Fator de transferència de resistència.

Abreviações: Em, estreptomicina; Ap, ampicilina; Cf, cloranfenicol; $C$, cefalotina; Sd, sulfadiazina; Tc, tetraciclina; $\mathrm{Cm}$. canamicina; Gm, gentamicina; ST, associação sulfametoxazol-trimetropin; lac, lactose; leu, leucina; thr, treonina; thi, tiamina.

misturadas em partes iguais e incubadas a 30 ou $37^{\circ} \mathrm{C}$ por 2 e 24 horas. Depois disto, eram diluidas convenienternente e plaqueadas em agar seletivo, incubando-se as placas por um período de 24 e 72 horas a 30 ou $37 \circ$ C. As colônias transconjugantes crescidas eram reisoladas em agar seletivo para confirmação, e eram testadas bioquimicamente pelas provas de indol $\mathrm{e}_{2} \mathrm{~S}$ em meio S.I.M. (Merck).

\section{Mobilização do plasmídeo}

Cultura das linhagens doadoras e $P$. mirabilis PM51 eram diluídas 1:10, misturadas em partes iguais e incubadas por 8 a 10 horas. Então era adicionado um volume igual de uma cultura diluida $1: 10$ da receptora E. coli LR1, incubando-se a mistura a $37^{\circ} \mathrm{C}$ por 24 horas. O procedimento de seleção era o mesmo descrito no item acima.

\section{Avaliação do peso molecular do plasmideo}

Os plasmideos foram isolados segundo a técnica de Guerry e cols ${ }^{7}$ e analisados por eletroforese em gel de agarose a $0,8 \%$. Utilizaram-se os plasmídeos pSF2124 (6,5 megadaltons), Sa (23 Md), RP4 (34 $\mathrm{Md})$ e EntP (54 MD) como marcadores de referência. As distâncias de migrações eram comparadas aos respectivos pesos moleculares em gráfico bilogaritmico.

\section{RESULTADOS}

Os clones E10f são estáveis quanto ao caráter lactose-positivo e nào revertem para o fenótipo que lhes deu origem, ou seja, E10. Esta última linhagem, de fenótipo lactose-negativo, começa a produzir papilas lactose-positivas após 48 horas (de onde se originam os clones E10f) e esta produção cresce com o tempo, predominando na cultura após 5 ou 7 dias.
O caráter Rlac das linhagens H975 e E10f era termostável a $42^{\circ} \mathrm{C}$ e não era eliminado pelo alaranjado de acridina. Nenhuma destas linhagens mostrouse produtora de colicina.

O caráter fermentaçāo de lactose das linhagens H975 e E10f perdia-se espontaneamente numa freqüência abaixo de $1 \%$; entretanto, as colônias resultantes não tinham o fenótipo tipicamente lactosenegativo (de cor branca no agar MacConkey), pois, eram de cor rosa pálida, que nos sugeriu uma variante de fermentação lenta (talvez devido a perda da sintese de permease, uma das três enzimas do operon lactose). Observamos que na linhagem $\mathrm{H} 975$ a perda do caráter lac era concomitante ao da resistência à canamicina.

O caráter Rlac não era transferivel por conjugação, seja na linhagem H975, seja na E10f. Entretanto, em ambas, oplasmideo Rlac foi mobilizado pelo RTF de $P$. mirabilis confirmando-se, portanto, a natureza plasmidial deste caráter. A eletroforese em gel de agarose também confirmou a presença de um plasmídeo único em ambas as linhagens e de mesmo peso molecular nos dois casos, estimado em 7,4 megadaltons, aproximadamente.

Nos experimentos de conjugação acima citados, obtinhamos crescimento numa freqüencia média de $10^{-5}$, entretanto, estas colônias, julgadas "a priori" transconjugantes, não cresciam nas mesmas placas seletivas quando reisoladas, e os testes bioquimicos revelaram tratar-se das salmonelas doadoras, e não de E. coli transconjugantes.

\section{DISCUSSÃO}

As linhagens H975 e E10f assemelham-se geneticamente àquelas variantes lactose-positivas isoladas em São Paulo1 ${ }^{2}$. A linhagem E10 também assemelha-se àquelas descritas como fermentadoras tardias da lactose ${ }^{15}$, também isoladas naquela cidade. 
Câmara FP, Cardoso MA, Almeida DF. Análise genética de Salmonella typhimurium fermentadoras de lactose isoladas no Rio de Janeiro. Revista da Sociedade Brasileira de Medicina Tropical 22: 81-83, Abr-Jun, 1989

Isto não significa, contudo, que as linhagens aqui descritas sejam originárias de São Paulo. Suassuna e cols ${ }^{14}$ descreveram a linhagem H975 em um caso de gastroenterite autóctone no Rio de Janeiro, e a linhagem E10 foi proveniente de isolamento anterior a $1972^{9}$, pelo menos 1 ano antes de Pessoa 13 ter relatado o isolamento de uma variante semelhante em São Paulo. Por outro lado, não houve situações epidêmicas no Rio de Janeiro em franco contraste com o que acontecia em São Paulo na década passada ${ }^{2}$. Entretanto, o fenômeno de ativação do operon lactose na linhagem E10 resultando no fenótipo E10f(lactosepositivo) pode indicar uma fonte comum para a origem das variantes lactose-positivas de São Paulo e a linhagem H975 do Rio de Janeiro. As variantes "lactose-tardias" ou formadoras de papilas em agar MacConkey poderiam ser a linhagem prototípica da qual se originaram as variantes lactose-positivas, uma vez que, como já vimos, os clones fermentadores isolados das papilas são geneticamente estáveis. Ocorrendo também no Rio de Janeiro como em São Paulo, o caráter cosmopolita da variante lactosetardia sofreria pressões seletivas a favor de variantes lactose-positivas, o que poderia ser uma hipótese de partida para se explicar a ocorrência destas em São Paulo e ausência no Rio de Janeiro.

Nos nossos experimentos, os plasmideos $\mathrm{H} 975$ e E10f não foram transferidos por conjugação, sendo demonstrados apenas por mobilização com um RTF. Neste sentido, nossos resultados estão de acordo com os de Le Minor e col ${ }^{10}$, que estudaram as variantes lactose-positivas de São Paulo. Por outro lado, plasmideos de baixo peso molecular tais como os do presente trabalho são geralmente não autotransferiveis ${ }^{3}$.

\section{SUMMARY}

Lactose fermenting Salmonella typhimurium are endemic in Sào Paulo, but not in Rio de Janeiro Two isolations are described from the latter city. These Rio de Janeiro strains have a plasmid of 7.4 megadaltons. These plasmids were not auto-transferable, were thermostable and were not eliminated by acridine orange. One of these strains arose from a plasmid that had the lactose operon repressed, leading us to speculate about the evolution of the lactose fermenting character in Brazilian Salmonella.

Key-words: Lactose fermenting Salmonella. Salmonella typhimurium Plasmid Epidemiology of Salmonella.

\section{REFERÊNCIAS BIBLIOGRÁFICAS}

1. Afonso MLT, Toledo MRF, Trabulsi LR. Natureza genética da fermentação de lactose em amostras de Salmonellas typhimurium. Revista de Microbiologia Sào Paulo 8:110-116, 1977.

2. Almeida PCA, Trabulsi LR. Características culturais, bioquímicas, sorológicas e virulência de amostras de Salmonella typhimurium fermentadoras de lactose. Revista de Microbiologia Sào Paulo 5:27-35, 1974.

3. Broda P. Plasmids. W.F. Freeman Co., Oxford, p. 14-15, 1979.

4. Câmara, FP. Metaestabilidade genética em uma Salmonella typhimurium isolada em esgoto do Rio de Janeiro. 11a Reunião Anual de Genética de Microorganismos, Londrina, p. 35, 1984.

5. Câmara FP, Costa GA, Hofer E, Almeida DF. Drug resistance in Salmonella strains isolated from raw sewage in Rio de Janeiro. Revista Brasileira de Biologia 42:421-424, 1982.

6. Clowes RC, Hayes W. Experiments in microbial genetics. Blackwell Scientific Publications, Oxford, 1968.

7. Guerry P, LeBlanc DJ, Falkow S. General method for the isolation of plasmid deoxyribonucleic acid. Journal of Bacteriology 116:1064-1066, 1973.

8. Guiso N, Ullmann A. Expression and regulation of lactose genes carried by plasmids. Journal of Bacteriology 127:691-697, 1976.

9. Hofer E, Costa GA. Investigações sobre a ocorrência de Salmonella em esgotos sanitários da cidade do Rio de Janeiro. Memórias do Instituto Oswaldo Cruz 70:221236, 1972.

10. Le Minor L, Coynault C, Pessoa GVA. Déterminisme plasmidique du caractère atypique "lactose-positif" de souches de $S$. typhimurium et de $S$. oranienburg isolées au Brésil lors d'epidemies de 1971 a 1973. Annales de Microbiologie Paris 125:261-285, 1974.

11. Meynell GG, Meynell E. Theory and practice in experimental bacteriology. Cambridge University P'ress, Cambridge, 1970.

12. Miller UH. Experiments in molecular genetics. Cold Spring Harbor Laboratories, New York, 1972.

13. Pessoa GVA. Sobre a ocorrência de uma variante de Salmonella typhimurium fermentadora de lactose. Revista do Instituto Adolfo Lutz 33:13-28, 1973.

14. Suassuna I, Suassuna IR, Judel VI. Isolamento de Salmonella typhimurium fermentadora de lactose, em caso autóctone no Rio de Janeiro. Revista da Sociedade Brasileira de Medicina Tropical 9:79-82, 1975.

15. Toledo MRF, Reis MHL, Murahovschi J, Cury R. Ramos SRTS, Fiore ES, Schussel EY, Trabulsi LR. Ocorrência de uma variante de Salmonella typhimurium que fermenta a lactose tardiamente. Revista de Microbiologia Sáo Paulo 10:103-105, 1979.

16. Yoshida Y, Terawaki Y, Nakaya R. R plasmids with thermosensitive transferability in Salmonella strains from humans. Microbiology and Immunology 22:735743, 1978. 